\title{
Taxonomic investigation of the Xanthium strumarium L. complex (Asteraceae) distributed in Iran inferred from morphological, palynological and molecular data
}

\author{
FARIBA NOEDOOST ${ }^{1, \vartheta}$, JAMIL VAEZI ${ }^{2, v v}$, SEDIGHEH NIKZAT SIAHKOLAEE ${ }^{3}$ \\ ${ }^{1}$ Department of Biology, Faculty of Science, Behbahan Khatam Alanbia University of Technology. Khuzestan, Iran \\ Tel.:+98-61-52721230, `email: noedoost@bkatu.ac.ir, fariba.noedoost@gmail.com. \\ 2Department of Biology, Faculty of Science, Ferdowsi University of Mashhad. Mashhad, Iran. "vemail: vaezi@um.ac.ir \\ ${ }^{3}$ Faculty of Life Sciences and Biotechnology, Shahid Beheshti University. Tehran, Iran \\ Manuscript received: 2 February 2021. Revision accepted: 25 March 2021.
}

\begin{abstract}
Noedoost F, Vaezi J, Nikzat Siahkolaee S. 2021. Taxonomic investigation of the Xanthium strumarium L. complex (Asteraceae) distributed in Iran inferred from morphological, palynological and molecular data. Biodiversitas 22: 1961-1974. Unclear species boundaries due to high morphological similarities lead to different opinions on Xanthium classification. To solve this problem, we conducted investigation on morphological, palynological and molecular (ITS sequencing) of three species of Xanthium (i.e., X. strumarium, X. sibiricum, and X. brasilicum) forming Xanthium strumarium complex in Iran. We randomly collected 110 plant individuals of the Xanthium strumarium complex as well as X. spinosum from 30 geographical populations in eight provinces of Iran. Pollen grains of 19 populations were studied by scanning electron microscope (SEM). Results obtained from the analysis of morphological characters showed that the three species, $X$. strumarium, X. brasilicum and $X$. sibiricum were placed nearly together specially $X$. strumarium and $X$. brasilicum are obviously overlapped. Palynological results indicated the pollen grains of section Acanthoxanthium (i.e., X. spinosum) and Xanthium (i.e., X. strumarium, X. sibiricum, and X. brasilicum) are clearly differing by their LM and SEM characters. However, no significant difference found between the pollen of $X$. strumarium and $X$. brasilicum. The Bayesian phylogenetic tree of the ITS region of rDNA sequences revealed that X. strumarium, X. sibiricum and X. brasilicum could not be discriminated as independent species. Overall, the morphological, palynological and molecular data provided evidence to synonymize $X$. brasilicum and $X$. strumarium with $X$. orientale and $X$. sibiricum with $X$. strumarium.
\end{abstract}

Keywords: Bayesian tree, complex, delimitation, heterogeneous habitat, morphometric, pollen

\section{INTRODUCTION}

Improvement in the utilization and conservation of biodiversity depends on the defensible species delimitation. Distinguishing species and establishing stable and consistent taxonomies is mostly important for many biological fields. The act of defining boundaries between species is on a comprehensive meaning species delimitation. It has been done in the past mostly relying on morphological traits, and on phenological and ecological evidence (Tomasello 2018). Plants growing in different habitats exhibit morphological and phenological differences. It is controversial to draw the obvious borders between putative taxa in their widely distributed areas (Moor et al. 2014). In this way, there are challenges about cryptic species and complexes, groups of organisms, or geographic areas that are poorly studied, and by differing opinions on species delimitation (Isaac et al. 2004; Mace 2004; Bickford et al. 2007).

Xanthium L. (Asteraceae) belongs to the subfamily Asteroideae, tribe Heliantheae and subtribe Ambrosiinae (Bentham 1873; Hoffmann 1890). It is a medicinal and weedy plant with global distribution (Alamet al. 2011) which may cause problems in sheep-grazing lands through its large spiny fruits and toxicity of fresh seedling (Cole et al. 1980; Alorfi et al. 2020). Moreover, the members of the genus are reported as invasive weeds for many crops in 28 countries (Hocking and Liddle 1986). However, different medical uses of the genus are mentioned, including for treatment of rhinitis, malaria, rheumatism, tuberculosis, cancer and ulcers (Ma et al. 1998; Gautamet al. 2007; Chandelet al. 2012; Tong et al. 2020).

Uncertainty in species boundaries due to high morphological similarities lead to different opinions on Xanthium classification. Different taxonomic concepts have been suggested, comprising several species, and other groupings the different taxa in a few extremely polymorphic species. The number of species comprised in Xanthium varies greatly. While more than 20 species were classified in two sections (Acanthoxanthium DC. and Euxanthium DC.) by Widder (1923), some botanists (e.g., Löve and Dansereau 1959; Löve 1976; Franco 1984) introduced only two species for the genus: namely $X$. spinosum L. (=Acanthoxanthium spinosum) -- a homogenous species with spiny stems, and X. strumarium L. -- a highly variable and heterogeneous species. According to Weaver and Lechowich (1982) and Caius (1986) classifications, the genus contains 20 and 25 species, respectively. Also Strother (2006) accepted Löve and Dansereau's (1959) opinion in flora of North America. 
Recently, Tomasello (2018) used plastid and nuclear markers and coalescent-based species delimitation methods (BP \& P and STACEY) to clarify the taxonomy and phylogeny of Xanthium sensu lato. He concluded that the genus comprises five species, including $X$. ambrosioides Hook \& Arn. (= Acanthoxanthiumam brosioides (Hook \& Arn.) D. Löve), X. spinosum L. (= Acanthoxanthium spinosum (L.) Fourr.), X. chinense Mill., X. orientale L. and $X$. strumarium L.

Xanthium spinosum and the $X$. strumarium complex (including $X$. strumarium, $X$. brasilicum and $X$. sibiricum) are distributed in ecologically heterogeneous landscapes in Iran, including in agricultural lands, ruderal and urban areas, seaside to high elevation, forest, temperate, arid and semi-arid regions (Rechinger 1989). This heterogeneous habitat could explain some of unclear overlapping traits in morphology and palynology. Distinguishable features applied in species separation of the complex are mostly including characters of fruits, e.g., size, form, pubescence, number and length of spines on the fruits, and hooks status of beaks and spines (Widder 1923; Löve and Dansereau 1959; Nadeau 1961; Hicks 1971). The great variation of fruits causes the species complex with many local ecotypes and forms (Löve and Dansereau 1959; Weaver and Lechowich 1982). There are several surveys based on morphological traits to clarify species delimitation in different countries, such as Italy, North America, and Bangladesh (McMillan 1974; Hare 1980; Blais and Lechowicz 1989; Baldoni et al. 2000; Dinelli et al. 2003). However, few molecular studies were implied for declaring relationships within the species complex (Wallace et al. 2012; Zhao and $\mathrm{Hu}$ 2014; Tomasello and Heubl 2017; Tomasello 2018). Several studies have emphasized the importance of the pollen morphological data in understanding the systematics and evolution of the Asteraceae (e.g. Skvarla and Turner 1966; Wagenitz 1976; Skvarla 1977; Wortley et al. 2008, 2012; Punt and Hoen 2009; Pereira Coutinho and Dinis 2009; Blackmore et al. 2010; Pereira Coutinho et al. 2012, 2021; Tellería et al. 2013; Bordbar and Mirtadzadini 2015).

However, Species delimitation in the $X$. strumarium complex encounters various difficulties because of extensive hybridization, great phenotypic plasticity, and morphological variation due to defensive mechanisms, resource availability, diverse latitudinal and habitat distribution, and colonization in disturbed habitats (McMillan 1974; Moran et al. 1981; Blais and Lechowicz 1989). In this study, we aim at resolving species delimitation in Xanthium species complex distributed in Iran, particularly between X. brasilicum and X. Strumarium using molecular tools as well as pollen and morphological data. The latter species do not have any obvious boundaries and form very intermediate biotypes.

\section{MATERIALS AND METHODS}

\section{Plant materials}

We sampled 110 plant individuals of the Xanthium species complex from 30 geographical populations in eight provinces of Iran (Table 1). The taxonomic identification of Xanthium species was accomplished based on Flora Iranica (Dittrich 1989). The voucher specimens have been deposited in the herbarium of Shahid Beheshti University, Tehran, Iran (HSBU) and in the herbarium of the Museum of Natural History in Vienna, Austria (W) (Table 1).

\section{Morphological studies}

Three to five specimens were randomly collected from each location for morphological studies. In total, 32 quantitative and qualitative morphological characters were measured or scored (Table 2). The morphological characters were standardized $($ Mean $=0$, Variance $=1)$ and used to establish the Euclidean distance among the pairs of specimens (Podani 2000; Sheidaiet al. 2014). The obtained distances were then used for clustering the samples using UPGMA (Un-weighted paired group using average), Neighbor-Joining (NJ), and PCoA (Principal coordinate analysis) (Podani 2000). The morphological differentiation among the species was investigated by applying ANOVA (Analysis of Variance) to identify the most variable morphological characters (Podani 2000). The MannWhitney U test was used to compare differences between two species. All univariate analyses were implemented using SPSS release 18.0.0 (SPSS Inc., Chicago, USA).

\section{Palynological studies}

Light microscopy and Scanning electron microscopy (SEM): Pollen grains of 19 populations were studied by using light microscopy (LM) and scanning electron microscope (SEM). The pollen samples were obtained mostly from herbarium materials. Five randomly collected specimens were investigated for each population. The pollen grains were prepared for LM using the standard methods described by Erdtman (1963). For LM, the pollen grains were photographed using an Olympus BX51 microscope with automatic camera, under (E40, 0.65) oil immersion (E100, 1.25), with a 10× eyepiece and measured with the software Image Tools Version 3.0. For SEM studies, pollen grains were attached to aluminum stubs with double-sided cellophane tape and coated with gold. The specimens were examined with a Phillips $\times$ L20 SEM. UTHSCSA Image Tool Version 3.0 was used to carry out required measurements. Ten to 30 fully developed pollen grains were randomly selected for analysis. Eighteen quantitative and two qualitative palynological features were used for multivariate analysis, including shape of pollen, polar axis $(\mathrm{P})$, equatorial diameter $(\mathrm{E}), \mathrm{P} / \mathrm{E}$ ratio, interval between colpi (IC), colpi length (CL), number of echinae in $20 \times 20 \mu \mathrm{m}^{2}$ area, interval between two echinae (IE), echinae length (EL), echinae width in base (EW), length of lines on the surface of echinae (LL), length of echinae top (LET), width of echinae top (WET), distance between the apices of two ectocolpi (d), equatorial diameter (D), apocolpium index (AI), pollen size (PS), exine thickness (ET), cavea thickness (CT) and type of echinae. Mean, standard deviations and ANOVA were calculated using IBM SPSS Statistics 19. The terminology used for the palynological descriptions followed by Barth and Melhem (1988) based on updates described by Punt et al. (2007) and Punt and 
Hoen (2009) for the Asteraceae pollen grains. Statistical analyses including PCoA were performed using PAST software for plotting variation among populations and species (Hammer et al. 2009). In order to group the species, the cluster analysis was performed using Neighbor-Joining (NJ) method.

Table 1. Populations of Xanthium species, their locality and voucher number included in the morphological (Mor.), palynological (P) and molecular (Mol.) studies collected in the present study

\begin{tabular}{|c|c|c|c|c|c|c|c|}
\hline $\begin{array}{l}\text { Pop } \\
\text { no. }\end{array}$ & Taxa & Province & Locality & Voucher no. & Mor. & $\mathbf{P}$ & Mol. \\
\hline 1 & X. brasilicum & West Azarbayejan & Khoy & Azizi2018600 (HSBU) & + & - & - \\
\hline 2 & & West Azarbayejan & Sardasht, Bioran & Azizi2018601 (HSBU) & + & - & - \\
\hline 3 & & Gilan & Masal, on road near the city center. & Nikzat2018602 (HSBU) & + & - & - \\
\hline 4 & & Razavi Khorasan & Do rahiAbghadferizi & Basiri2018603 (HSBU) & + & - & - \\
\hline 5 & & Razavi Khorasan & Andadvaabghad, poshtHaronie & Basir2018604 (HSBU) & + & - & - \\
\hline 6 & & Razavi Khorasan & Pardis University of Mashhad & Basiri2018605 (HSBU) & + & - & + \\
\hline 7 & & Tehran & Karaj, Botany Garden & Nikzat2018606 (HSBU) & + & - & - \\
\hline 8 & & Tehran & Lavasan, Emamkhomeyni Bolívar & Nikzat2018607 (HSBU) & + & - & - \\
\hline 9 & & Mazandaran & Babol & Nikzat2018608 (HSBU) & + & + & - \\
\hline 10 & & Mazandaran & Haraz, in Road to Amol, near Ask. & Nikzat2018609 (HSBU) & + & - & - \\
\hline 11 & & Mazandaran & Savadkooh & Nikzat2018610 (HSBU) & + & - & - \\
\hline 12 & & Mazandaran & Kiasar & Nikzat2018611 (HSBU) & + & + & - \\
\hline 13 & & Mazandaran & Babolsar, Parking, near the beach & Nikzat2018612 (HSBU) & + & - & + \\
\hline 14 & & Gilan & Pahlavi, Ghazian & Mir kamali20141 (W) & + & - & + \\
\hline 15 & X. sibiricum & North Khorasan & BeinShirvan-Ghochan & Rechinger11850 (W) & + & - & + \\
\hline 16 & & Mazandaran & Amol & Nikzat2018613 (HSBU) & + & - & - \\
\hline 17 & & Mazandaran & HezarJarib, & Nikzat2018614 (HSBU) & + & - & - \\
\hline 18 & & Mazandaran & Kiasar, in road to Sari & Nikzat2018615 (HSBU) & + & + & + \\
\hline 19 & & Mazandaran & Savadkooh, Doab, in road to Veresk & Nikzat2018616 (HSBU) & + & - & - \\
\hline 20 & & Wardak & Maidantal, Reisfeld W Maidan & Breckle05110 (W) & + & - & + \\
\hline 21 & X. spinosum & Golestan & Aliabad, beginning city, in road & Nikzat2018617 (HSBU) & + & - & + \\
\hline 22 & & Mazandaran & HezarJarib, Neka region. & Nikzat2018618 (HSBU) & + & - & - \\
\hline 23 & & Mazandaran & Sari, in road to Ghaemshahr & Nikzat2018619 (HSBU) & + & + & - \\
\hline 24 & & Mazandaran & Kiasar & Nikzat2018620 (HSBU) & + & + & - \\
\hline 25 & & Mazandaran & $\begin{array}{l}\text { Babol to Babolsar highway, initiation } \\
\text { of road. }\end{array}$ & Nikzat2018621 (HSBU) & + & - & - \\
\hline 26 & X. strumarium & Hamedan & Hamedan & Sabeti3859 (W) & + & - & + \\
\hline 27 & & Gilan & Masal & Nikzat2018622 (HSBU) & + & - & - \\
\hline 28 & & Mazandaran & Mahmood Abad to Amol. In road & Nikzat2018623 (HSBU) & + & - & - \\
\hline 29 & & Razavi Khorasan & Mashhad Ferizi & Basiri2018624 (HSBU) & + & + & - \\
\hline 30 & & North Khorasan & Bojnourd & Terme \& Matine01877 (W) & + & - & + \\
\hline
\end{tabular}

Table 2. Morphological characters studied

\begin{tabular}{|c|c|c|c|c|c|}
\hline No. & Abbrev. & Morphological characters & No. & Abbrev. & Morphological characters \\
\hline 1 & SS & Spine in stem $($ absent $=1 ;$ present $=2)$ & 17 & FSh & Fruit shape (elliptic $=1 ;$ ovate $=2$ ) \\
\hline 2 & Lco & Leaf color on both sides $($ green $=1 ;$ two color $=2)$ & 18 & FB & Fruit base (pulled $=1 ;$ fasciculated $=2$ ) \\
\hline 3 & LB & Leaf base $($ cordate $=1 ;$ wedge $=2)$ & 19 & BL & Bur length $(\mathrm{cm})$ \\
\hline 4 & NLLo & Number of leaf lobes & 20 & BW & Bur width $(\mathrm{cm})$ \\
\hline 5 & LL & Leaf length $(\mathrm{cm})$ & 21 & BLW & Bur length/ Bur width \\
\hline 6 & LW & Leaf width $(\mathrm{cm})$ & 22 & $\mathrm{BeL}$ & Beak length $(\mathrm{mm})$ \\
\hline 7 & PL & Petiole length $(\mathrm{cm})$ & 23 & BS & Beak situation $($ curved $=1 ;$ right $=2)$ \\
\hline 8 & PW & Petiole width $(\mathrm{cm})$ & 24 & HS & $\begin{array}{l}\text { Hook situation }(\text { parallel }=1 ; \text { converge }=2 ; \\
\text { divergent }=3 \text {; }\end{array}$ \\
\hline 9 & LLW & Leaf length/ Leaf width & 25 & Fspd & Fruit spine density $($ dense $=1 ;$ scattered $=2)$ \\
\hline 10 & LLP & Leaf length/ Petiole length & 26 & FT & Fruit trichrome density $($ dense $=1 ;$ scattered $=2$ ) \\
\hline 11 & $\mathrm{CoL}$ & Corolla length $(\mathrm{mm})$ & 27 & SpT & Spine tip in fruit \\
\hline 12 & CoW & Corolla width $(\mathrm{mm})$ & 28 & NSp & Number of spines on $5 * 5 \mathrm{~mm}$ surface of fruit \\
\hline 13 & LCoL & Length of corolla lobes (mm) & 29 & SL & Spine length (mm) \\
\hline 14 & CoLW & Corolla length/ Corolla width & 30 & $\mathrm{SpWb}$ & Spine width at base (mm) \\
\hline 15 & AnL & Anther length (mm) & 31 & SpLW & Spine length/ Spine width \\
\hline 16 & FL & Filament length $(\mathrm{mm})$ & 32 & SpTd & $\begin{array}{l}\text { Trichrome in spine (up to } 1 / 3=1 ; \text { up to } 2 / 3= \\
2 ; \text { absent }=3 \text { ) }\end{array}$ \\
\hline
\end{tabular}




\section{Molecular study}

Genomic DNA was extracted using the CTAB method (Doyle and Doyle 1987) method. The quality of extracted DNA was examined by running on $0.8 \%$ agarose gel. The internal transcribed regions (ITS) were amplified using the universal primers ITS4 and ITS5 described by White et al. (1990). The amplification reaction was performed in $25 \mu \mathrm{l}$ volumes containing 10X PCR buffer (Fermentas, Lithuania), $2.5 \mu 1 \mathrm{MgCl}_{2}$ (25 mM, Fermentas, Lithuania), $0.2 \mathrm{mM}$ of each dNTP, $2 \mathrm{U}$ of Taq polymerase, $100 \mu \mathrm{mol} / \mathrm{L}$ of the universal primers and ca. $200 \mathrm{ng}$ genomic DNA. Amplifications were carried out under the following program: one initial denaturation step at $95{ }^{\circ} \mathrm{C}$ for $5 \mathrm{~min}$ followed by 35 cycles of $1 \mathrm{~min}$ for denaturation at $95^{\circ} \mathrm{C}$, annealing at $54{ }^{\circ} \mathrm{C}$ for $45 \mathrm{~s}$, and extension at $72{ }^{\circ} \mathrm{C}$ for 1 min. The reaction was terminated with a final extension for $3 \mathrm{~min}$ at $72 \mathrm{C}$. PCR products were visualized on $2.5 \%$ agarose gel through GelRed ${ }^{\mathrm{TM}}$ Nucleic Acid Gel Staining. Sequencing was conducted using Macrogen's sequencing service (Macrogen Inc., Korea). Furthermore, ITS sequences from 12 Xanthium species have been obtained from GenBank (X. ambrosioides KY215719, X. spinosum KY215702, $X$. sibiricum GU724274, X. strumarium KY215701, $X$. abyssinicum KY215720, X. albinum KY215706, X. californicum KY215724, X. echinatum KY215716, $\quad X$. orientale KY215704, $X$. pungens KY215703, X. saccharatum KY215700, X. indicum KY215707) and were added to the molecular matrix. Ambrosia artemisiifolia (KY215732) was also used as outgroup.

Sequences were edited using Sequencher version 5.2.4 (Gene Codes Inc., Ann Arbor, Michigan) and aligned using Clustal W (Thompson et al. 1994) as performed in BioEdit Sequence Alignment Editor (Hall 1999). We subsequently used the "simple indel coding" method (Simmons and Ochoterena 2000) to code the indels (insertions/deletions) using SeqState ver. 1.25 (Müller 2005). In order to determine the best evolutionary model fitted for the dataset, the hierarchical likelihood ratio test was calculated using MrModeltest 2.2 (Nylander 2004). The ITS dataset was investigated using the Bayesian MCMC inference for one million generations, sampling every 100 generations. The convergence and burn-in phase were determined using Tracer ver. 1.4 (Rambaut and Drummond 2007). Trees were visualized using TreeView ver. 1.6.6 (Page 2001).

\section{RESULTS AND DISCUSSION}

\section{Morphological analysis}

Statistical analysis (ANOVA) indicated that the characters including the bur length to width ratio (BLW), fruit base (FB), beak length (BeL) and Hook situation (HS) could not be used to discriminate among the taxa under study (Table 3). Results of the statistical Mann-Whitney test showed that 22, 19 and 22 of $32(68.7 \%, 59.3 \%$ and $69.7 \%$ ) characters can significantly discriminate $X$. spinosum from $X$. brasilicum, $X$. strumarium and $X$. sibiricum, respectively. Of 32 morphological variables, 13 $(40.6 \%)$ characters are appropriate to differentiate $X$. brasilicum from $X$. strumarium. Likewise, 15 of 32 (47\%) traits seem to be useful to discriminate $X$. sibiricum from $X$. brasilicum and $X$. strumarium (Table 3 ). Moreover, there is no species delimitation in the foliar characteristics among the members of the $X$. strumarium complex (Table 3 ).

Results obtained from the PCoA (Figure 1) related to the 32 quality and quantity features illustrated that the three species under study as well as $X$. spinosum form two distinct groups. All individuals of $X$. spinosum located on the right side of the graph. The PCoA analysis did not support the taxonomic segregation of the studied species where the three species of the $X$. strumarium complex were placed nearly together on the left side of the graph.

The PCoA results, which represented the first principal component ( $\mathrm{PCo} 1$ ) $31.63 \%$ of the total variations, the second ( $\mathrm{PCo} 2) 19.06 \%$, the third ( $\mathrm{PCo} 3)$ 10.87\%, the fourth (PCo4) 8.87\%, and the fifth (PCo5) 6.79\%, showed that features such as the ratio of leaf length to petiole length (0.465), the ratio of spine length to width $(0.32818)$ and petiole length (0.301) in the first component (PCo1), width of corolla (0.60718) and the ratio of corolla length to width (0.425) in the PCo2, and bur width (0.413) in the $\mathrm{PCo}$, spine width at base (0.815) in $\mathrm{PCo} 4$ and anther length $(0.88)$ in $\mathrm{PCo} 5$ were the most variable morphological characteristics (Table 4).

The NJ analysis (Figure 2) separated X. spinosum from the species complex. The three species under study slightly overlapped together and the use of morphological features is somewhat problematic. The leaf and fruit variations are obviously overlapped among the members of the $X$. brasilicum and $X$. strumarium (Figures 3-4). For example, we observed two specimens of the same population of $X$. brasilicum (Mashhad population, Figure 4, i) with differences in density and size of spines on fruits. $X$. sibiricum's burs (Figure $4 \mathrm{j}-\mathrm{m}$ ) are very distinct from the others of the complex. And looking at table 4, spine length/spine width (0.307) and spine width at the base $(0.28)$ seem to be also somewhat responsible for scattering samples along axis 2 .

\section{Palynological studies}

According to the terminology of Punt and Hoen (2009), pollen type of the species complex overall seems to be similar to that of X.strumarium type. Pollen grains are mainly 3-zonocolporate and rarely 4-zonocolporate (Figure 6) with very short, narrow and acutecolpus (Figure 5). Apocolpium index is large. Cavea is distinct (Figure 6) and sculpturing in the members of the complex is scabrate (echinate with spines $<1 \mu \mathrm{m}$ ) (Figure $5 \mathrm{c}, \mathrm{f}, \mathrm{i}$ ), acute at the top and very broad in base, while it is conical echinate with obtuse tip in X.spinosum (Figure 51). Outlines of pollen in the equatorial view are oblate- spheroidal (Figure 5b), spheroidal (Figure 5e), subprolate (Figure 5h) and prolatespheroidal (Figure 5k). 
Table 3. Description and results of univariate analyses of the morphological characters

\begin{tabular}{|c|c|c|c|c|c|c|c|c|c|c|c|c|c|c|c|}
\hline \multirow{2}{*}{$\begin{array}{l}\text { Character } \\
\text { Abbrev. }\end{array}$} & \multirow[t]{2}{*}{ ANOVA Sig. } & \multicolumn{4}{|c|}{ Mean } & \multicolumn{4}{|c|}{ Std. Dev. } & \multicolumn{6}{|c|}{ Mann-Whitney test ( $P$-value $)$} \\
\hline & & Spin & Bras & Stru & Sibr & Spin & Bras & Stru & Sibr & Spin/Bras & Spin/Stru & Spin/Sibr & Bras/Stru & Bras/Sibr & Stru/Sibr \\
\hline SS & . & 1 & 2 & 2 & 2 & 0 & 0 & 0 & 0 & 0 & 0 & 0 & 0.639 & 0.017 & 0.021 \\
\hline Lco & . & 2 & 1 & 1 & 1 & 0 & 0 & 0 & 0 & 0 & 0 & 0 & 0.09 & 0.087 & 0.002 \\
\hline LB & . & 1 & 2 & 2 & 2 & 0 & 0 & 0 & 0 & 0 & 0 & 0 & 0.048 & 0.076 & 0.002 \\
\hline NLLo & .000 & 3 & 4.98 & 5 & 4.9 & 0 & 0.135 & 0 & 0.308 & 0 & 0 & 0 & 0.019 & 0.815 & 0.006 \\
\hline LL & .000 & 4.16 & 8.09 & 8.50 & 6.91 & 0.666 & 1.844 & 1.980 & 1.446 & 0 & 0 & 0 & 0.002 & 0.243 & 0.105 \\
\hline LW & .000 & 1.68 & 7.41 & 8.67 & 6.53 & 0.393 & 2.096 & 1.950 & 1.285 & 0.022 & 0.246 & 0.003 & 0.516 & 0.857 & 0.174 \\
\hline PL & .000 & 1.06 & 7.73 & 9.28 & 6.35 & 0.668 & 2.787 & 2.800 & 1.557 & 0 & 0 & 0 & 1 & 1 & 1 \\
\hline PW & .138 & 0.17 & 0.22 & 0.20 & 0.23 & 0.047 & 0.122 & 0.061 & 0.101 & 0 & 0 & 0 & 1 & 1 & 1 \\
\hline LLW & .000 & 2.53 & 1.12 & 0.98 & 1.06 & 0.435 & 0.159 & 0.080 & 0.135 & 0 & 0 & 0 & 0.627 & 0.112 & 0.247 \\
\hline LLP & .000 & 5.22 & 1.11 & 0.98 & 1.12 & 2.430 & 0.251 & 0.326 & 0.228 & 0 & 0 & 0 & 1 & 1 & 1 \\
\hline $\mathrm{CoL}$ & .000 & 1.87 & 2.38 & 1.72 & 2.15 & 0.390 & 0.675 & 0.262 & 0.451 & 0 & 0.07 & 0.23 & 0 & 0.056 & 0.002 \\
\hline CoW & .000 & 1.08 & 3.09 & 0.57 & 0.59 & 0.096 & 3.228 & 0.103 & 0.199 & 0.664 & 0 & 0 & 0 & 0 & 0.65 \\
\hline $\mathrm{LCoL}$ & .000 & 0.37 & 0.58 & 0.49 & 0.25 & 0.092 & 0.269 & 0.086 & 0.076 & 0 & 0.002 & 0 & 0.624 & 0 & 0 \\
\hline CoLW & .000 & 1.73 & 1.76 & 3.13 & 3.99 & 0.356 & 1.158 & 0.769 & 1.476 & 0.782 & 0 & 0 & 0 & 0 & 0.089 \\
\hline AnL & .564 & 1.04 & 1.16 & 1.51 & 1.09 & 0.159 & 0.801 & 2.317 & 0.176 & 0.126 & 0.036 & 0.53 & 0.23 & 0.051 & 0.014 \\
\hline FL & .809 & 1.20 & 1.35 & 1.13 & 1.44 & 0.206 & 1.309 & 1.468 & 0.357 & 0.599 & 0 & 0.047 & 0.058 & 0.063 & 0.063 \\
\hline FSh & .000 & 1 & 1.47 & 1 & 1 & 0 & 0.504 & 0 & 0 & 0 & 1 & 1 & 0.002 & 0 & 1 \\
\hline FB & .574 & 1 & 1.04 & 1 & 1 & 0 & 0.189 & 0 & 0 & 0.368 & 1 & 1 & 0.488 & 0.391 & 1 \\
\hline BL & .000 & 1.42 & 2.67 & 1.82 & 1.53 & 0.160 & 0.577 & 0.636 & 0.226 & 0 & 0.148 & 0.081 & 0 & 0 & 0.251 \\
\hline BW & .000 & 0.82 & 1.41 & 1.06 & 0.79 & 0.217 & 0.673 & 0.519 & 0.191 & 0.003 & 0.236 & 0.507 & 0.055 & 0.001 & 0.308 \\
\hline BLW & .074 & 1.82 & 2.23 & 1.88 & 2.04 & 0.394 & 0.814 & 0.437 & 0.601 & 0.132 & 0.864 & 0.29 & 0.369 & 0.719 & 0.337 \\
\hline $\mathrm{BeL}$ & .000 & 1.63 & 5.17 & 3.65 & 2.41 & 0.443 & 0.993 & 1.224 & 0.569 & 1 & 1 & 1 & 1 & 1 & 1 \\
\hline BS & . & 1 & 1 & 1 & 1 & 0 & 0 & 0 & 0 & 0 & 0 & 0 & 0 & 0.005 & 0 \\
\hline HS & .000 & 1 & 2.69 & 2 & 3 & 0 & 0.466 & 0 & 0 & 1 & 1 & 1 & 1 & 1 & 1 \\
\hline Fspd & . & 1 & 1 & 1 & 2 & 0 & 0 & 0 & 0 & 1 & 1 & 0 & 1 & 0 & 0 \\
\hline FT & .000 & 1 & 1.02 & 1 & 2 & 0 & 0.135 & 0 & 0 & 0.527 & 1 & 0 & 0.627 & 0 & 0 \\
\hline $\mathrm{SpT}$ & . & 2 & 2 & 2 & 2 & 0 & 0 & 0 & 0 & 0.001 & 0.655 & 0 & 0.002 & 0 & 0 \\
\hline $\mathrm{NSp}$ & .000 & 9.68 & 11.3 & 9.46 & 5.7 & 1.249 & 1.860 & 1.266 & 0.864 & 0 & 0.252 & 0 & 0 & 0 & 0.001 \\
\hline SL & .000 & 3.02 & 5.34 & 3.6 & 2.07 & 0.393 & 1.098 & 1.448 & 0.406 & 0 & 0 & 0 & 0.231 & 0.325 & 0.239 \\
\hline $\mathrm{SpWb}$ & .001 & 0.10 & 0.58 & 0.71 & 0.9 & 0.021 & 0.262 & 0.383 & 1.444 & 0 & 0 & 0 & 0.001 & 0 & 0.103 \\
\hline SpLW & .000 & 29.6 & 12.6 & 6.32 & 4.95 & 5.362 & 12.306 & 2.884 & 3.409 & 0 & 0 & 1 & 1 & 0 & 0 \\
\hline SpTd & .000 & 1 & 2.02 & 2 & 1 & 0 & 0.359 & 0 & 0 & 0 & 0 & 0 & 0 & 0 & 0.005 \\
\hline
\end{tabular}


Table 4. Eigen vectors of the principal components axes

\begin{tabular}{|c|c|c|c|c|c|}
\hline & PC 1 & PC 2 & PC 3 & PC 4 & PC 5 \\
\hline Leaf base & 0.14879 & 0.016653 & 0.05697 & 0.02368 & 0.02072 \\
\hline Leaf color on both sides & 0.21689 & 0.024275 & 0.083042 & 0.034512 & 0.030202 \\
\hline Spine in stem & 0.14879 & 0.016653 & 0.05697 & 0.02368 & 0.02072 \\
\hline Fruit trichrome density & 0.022179 & 0.18788 & 0.16887 & 0.060647 & 0.12273 \\
\hline Fruit shape & 0.11352 & 0.1142 & 0.14319 & 0.039138 & 0.05594 \\
\hline Beak situation & $5.66 \mathrm{E}-20$ & $8.91 \mathrm{E}-18$ & $3.49 \mathrm{E}-17$ & $1.30 \mathrm{E}-16$ & $5.33 \mathrm{E}-17$ \\
\hline Spine tip & $1.82 \mathrm{E}-20$ & $4.65 \mathrm{E}-18$ & $2.70 \mathrm{E}-17$ & $9.15 \mathrm{E}-17$ & $2.46 \mathrm{E}-17$ \\
\hline Spine trichrome density & 0.15143 & 0.12014 & 0.05703 & 0.08504 & 0.060302 \\
\hline Fruit base & 0.005595 & 0.026075 & 0.04388 & 0.047672 & 0.008887 \\
\hline Fruit spine density & 0.019727 & 0.19966 & 0.14659 & 0.042442 & 0.13817 \\
\hline Hook situation & 0.18691 & 0.030209 & 0.03065 & 0.02612 & 0.0775 \\
\hline Leaf length & 0.16817 & 0.035723 & 0.00388 & 0.11058 & 0.03765 \\
\hline Leaf width & 0.26245 & 0.038588 & 0.0607 & 0.15249 & 0.07191 \\
\hline Leaf length/ Leaf width & 0.27516 & 0.019637 & 0.12794 & 0.086023 & 0.067408 \\
\hline Petiole length & 0.30106 & 0.0085361 & 0.02645 & 0.2179 & 0.01884 \\
\hline Leaf length/ Petiole length & 0.46572 & 0.053468 & 0.19886 & 0.16505 & 0.10592 \\
\hline Bur length & 0.15771 & 0.13248 & 0.18628 & 0.04139 & 0.029322 \\
\hline Bur width & 0.16491 & 0.093639 & 0.41122 & 0.07297 & 0.06567 \\
\hline Bur length/ Bur width & 0.01165 & 0.043222 & 0.21706 & 0.029977 & 0.01966 \\
\hline spine length & 0.12745 & 0.2177 & 0.21144 & 0.02357 & 0.02936 \\
\hline Spine width at base & 0.26443 & 0.28092 & 0.2015 & 0.81553 & 0.077424 \\
\hline spine length/ Spine width & 0.32818 & 0.30736 & 0.054772 & 0.06698 & 0.13123 \\
\hline Number of leaf lobes & 0.11782 & 0.0137 & 0.0358 & 0.02118 & 0.0097 \\
\hline Petiole width & 0.10033 & 0.026643 & 0.05832 & 0.03993 & 0.040362 \\
\hline Beak length & 0.22396 & 0.1896 & 0.095278 & 0.02548 & 0.046926 \\
\hline Corolla length & 0.060419 & 0.041246 & 0.087608 & 0.054111 & 0.021166 \\
\hline Corolla width & 0.12094 & 0.60718 & 0.37043 & 0.39219 & 0.18482 \\
\hline Length of corolla lobes & 0.11049 & 0.16875 & 0.26388 & 0.038668 & 0.2268 \\
\hline Corolla length/ Corolla width & 0.054727 & 0.42547 & 0.031198 & 0.09235 & 0.01706 \\
\hline Anther length & 0.008051 & 0.017858 & 0.38901 & 0.0195 & 0.88031 \\
\hline Filament length & 0.042 & 0.00011054 & 0.33179 & 0.11769 & 0.15312 \\
\hline Number of spines on $5 \times 5 \mathrm{~mm}$ surface of fruit & 0.033425 & 0.15014 & 0.14061 & 0.0336 & 0.1011 \\
\hline
\end{tabular}

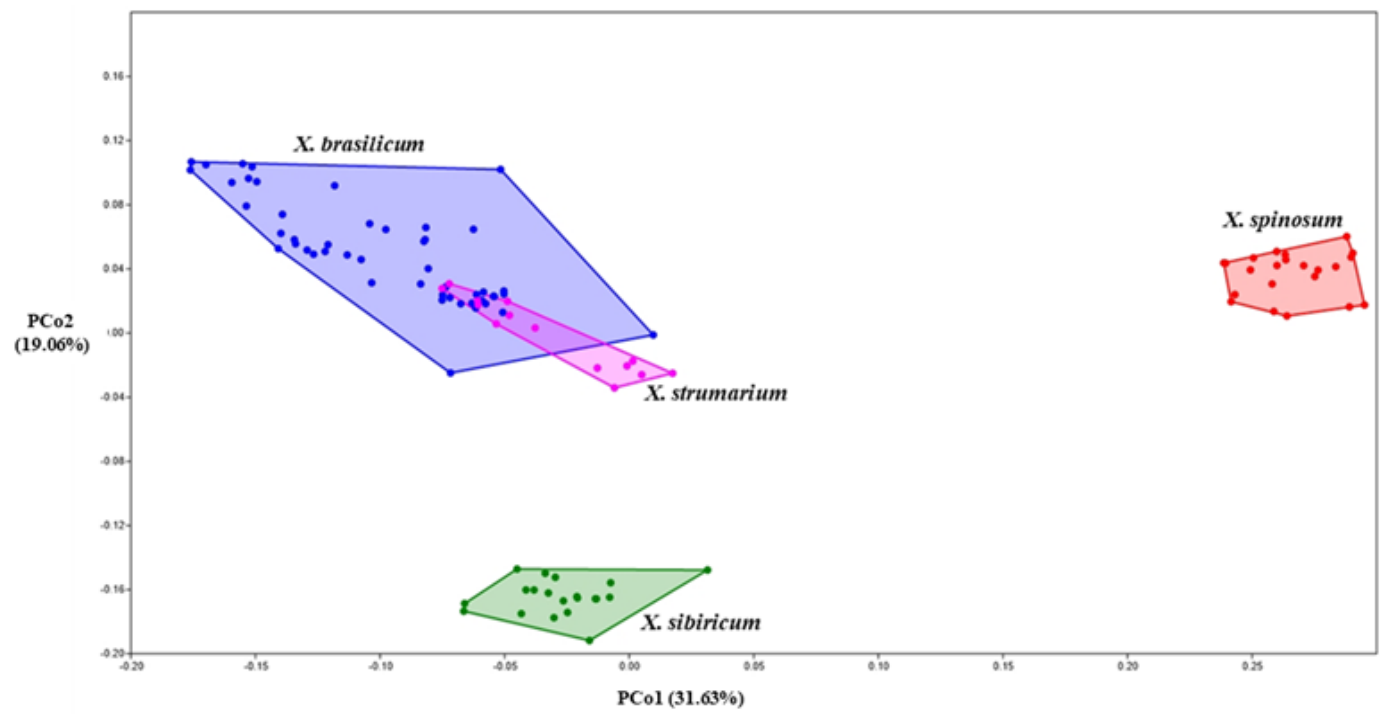

Figure 1. PCoA graph of morphological features based on Euclidian distance 


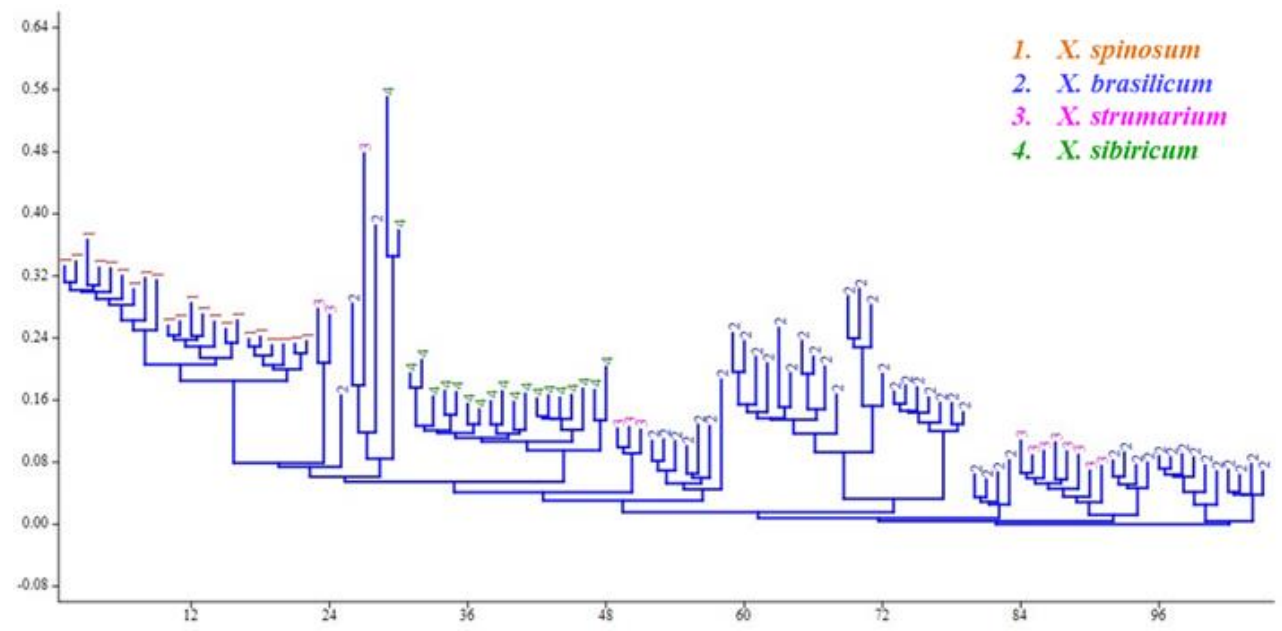

Figure 2. NJ plot of morphological features of Xanthium species
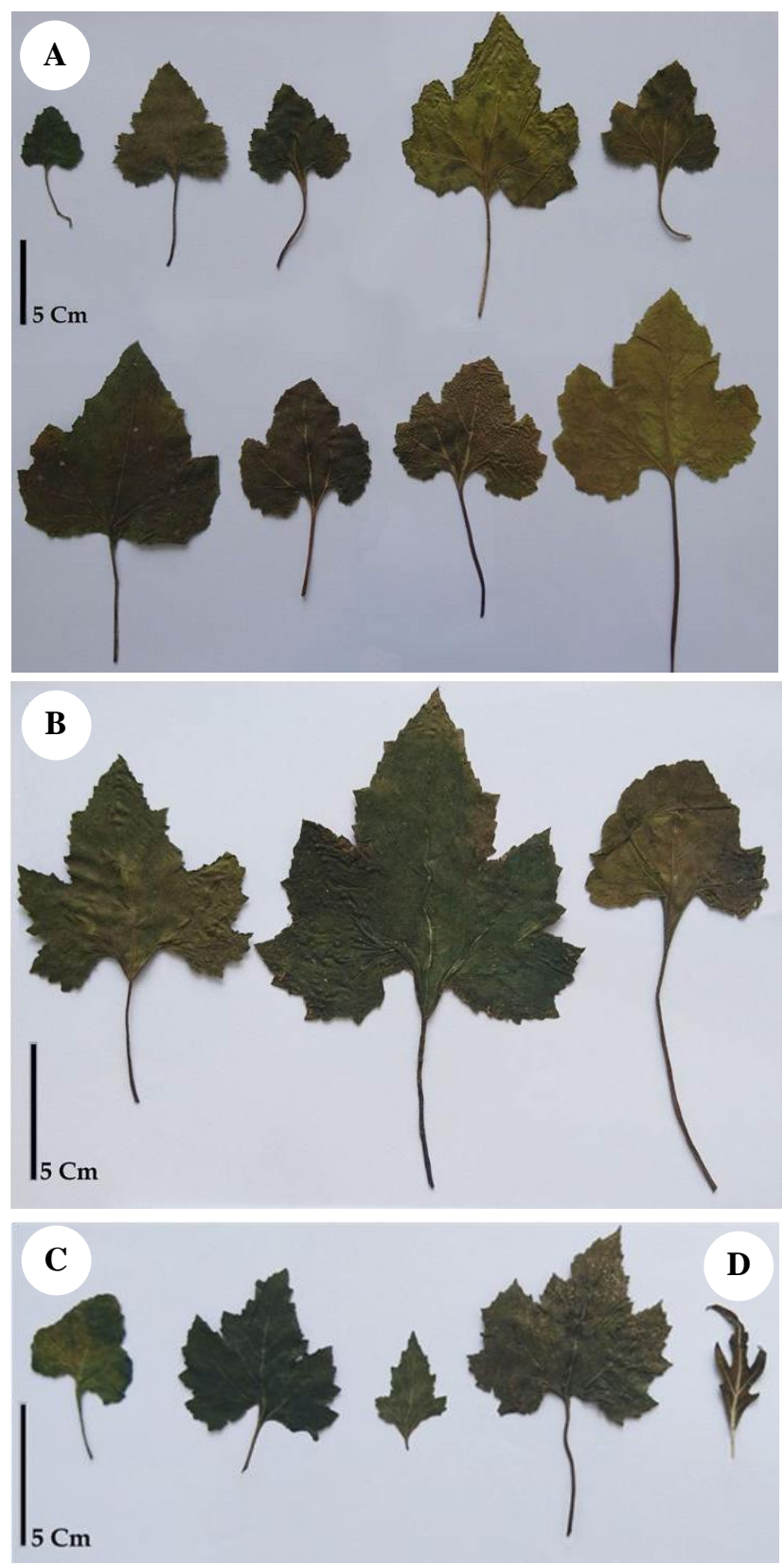

Figure 3. Diversity of leaves in different population of Xanthium species in terms of size and shape; a: X. brasilicum (left to right in up: Sardasht, Karaj, Lavasan, Haraz road, Doab) In down: Babol, Abghad, Frizi, Mashhad). b: X. strumarium (left to right: Masal, Mahmoodabad, Frizi). c: X. sibiricum (left to right: Hezarjarib, Kiasar, Amol, Doab) d: X. spinosum (Dargaz road)

Mean length of the pollen grains varied from $23.99 \mu \mathrm{m}$ (X. brasilicum) to $28 \mu \mathrm{m}$ (X. strumarium), while the width varied from $24.03 \mu \mathrm{m}$ (X. spinosum) to $24.93 \mu \mathrm{m}(X$. brasilicum). The main colpus length and the $\mathrm{P} / \mathrm{E}$ ratio varied from $1.18 \mu \mathrm{m}(X$. spinosum) to $8.82 \mu \mathrm{m}(X$. sibiricum) and from $0.96 \mu \mathrm{m}$ (X. brasilicum) to $1.15 \mu \mathrm{m}$ (X. strumarium), respectively. The main features of the pollen grains of the Xanthium species under study are summarized in Table 5.

The PCoA analysis of the pollen features clearly separated $X$. spinosum from the members of the Xanthium complex (Figure 7), whereas the individuals of the complex were placed together in the reduced-space graph. The PCo1 and PCo 2 axes account for $94 \%$ of the total variation. The PCoA results showed that the features such as pollen size, length, density and tip of echinate, shape of pollen, exine thickness were the most variable pollen characteristics.

\section{Molecular studies}

A total of 712 nucleotides including coded indels related to 22 taxa were integrated into the Bayesian analysis. Of these, 623 characters were constant, 42 parsimony-uninformative and 47 characters were parsimony-informative. The ITS sequences were analyzed using Bayesian inference with the $G T R+G$ nucleotide substitution model based on the Akaike information criterion generated a $50 \%$ majority-rule consensus tree (Figure 8). Except for X. ambrosioides and X. spinosum which occurred in a well-supported clade, the remaining Xanthium species included in the study formed a poorly resolved polytomous clade possibly resulting from relatively low sequence divergence. Within the latter clade, the members of the complex under study were placed intermixed with the other Xanthium species. 


\section{Discussion}

Rechinger (1989) in Flora Iranica, separated $X$. spinosum from other Xanthium species with spiny stem and color of abaxial leaf surface. On the other hand, shape and density of fruit spines are used to differentiate between $X$. brasilicum and $X$. strumarium, so that $X$. brasilicum has ovate-subcircular fruit with high density of spines while $X$. strumarium and $X$. sibiricum have oval fruits with low density of spine, especially near the apex. Thickness of spine at base and squeezing of fruits in base separated these two latter species from each other (Figure 4). However, in Flora of Turkey (Davis 1975), the genus consists of two species including, $X$. spinosum and $X$. strumarium with two subspecies: $X$. stumarium subsp. strumarium L. and $X$. stumarium subsp. covanillesii (Schouw) D. Löve \& P.Dansereau (syn: X. brazilicum Vellozo, X.italicum Moretti in Brugnat).

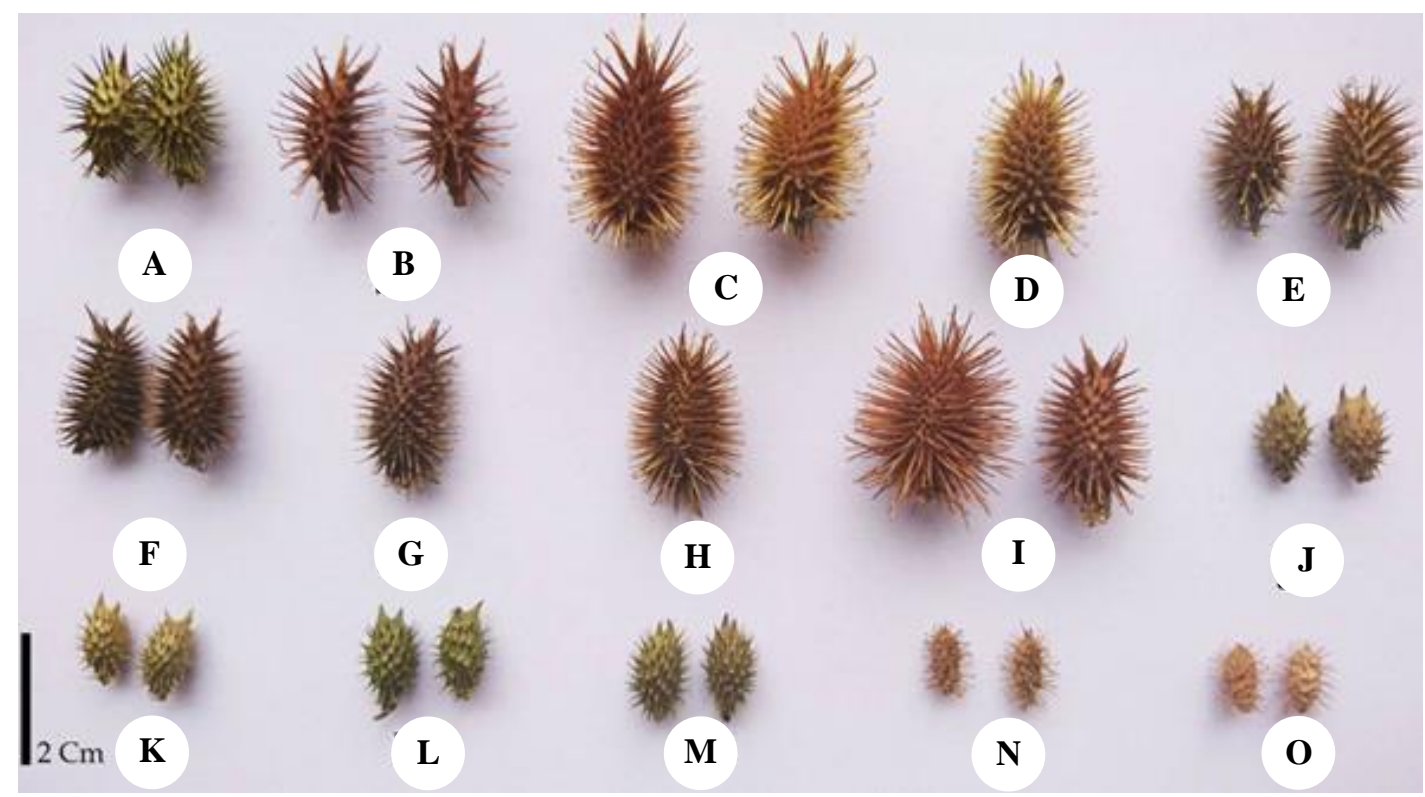

Figure 4. Diversity of fruits in different population of Xanthium species in terms of size, shape and spine density; X. strumarium (a, Mahmoodabad; b, Mashhad); X. brasilicum (c, Sardasht; d, Lavasan; e, Karaj, f, Haraz road; g, Babol; h, Kiasar; i, Mashhad), X. sibiricum (j, Kiasar; k, Doab; 1, Hezarjerib; m, Amol); X. spinosum (n, Sari; o, Mashhad)

Table 5. Details of examined characters of Xanthium sp. pollen specimens in this study

\begin{tabular}{|c|c|c|c|c|c|c|c|c|c|c|}
\hline Specimen & SP & $\mathbf{P}(\mu)$ & $\mathbf{P} / \mathbf{E}$ & $\mathbf{E}(\mu)$ & $\operatorname{IC}(\mu)$ & $\mathbf{C L}(\boldsymbol{\mu})$ & NE & $\mathbf{I E}(\boldsymbol{\mu})$ & $\mathbf{E L}(\mu)$ & $\mathbf{E W}(\mu)$ \\
\hline X. brasilicum & $\begin{array}{l}\text { Oblate- } \\
\text { spheroidal }\end{array}$ & $23.99 \pm 0.46$ & 0.96 & $24.93 \pm 0.21$ & $16.02 \pm 0.19$ & $7.59 \pm 0.99$ & $20 \pm 4$ & $0.55 \pm 0.09$ & $0.88 \pm 0.13$ & $1.81 \pm 0.18$ \\
\hline X. strumarium & Sunprolate & $28 \pm 0.62$ & 1.15 & $24.28 \pm 1$ & $17.45 \pm 1.24$ & $6.67 \pm 0.68$ & $18 \pm 3$ & $2 \pm 0.35$ & $0.58 \pm 0.18$ & $1.96 \pm 0.64$ \\
\hline$X$. sibiricum & $\begin{array}{l}\text { Prolate- } \\
\text { spheroilda }\end{array}$ & $25.57 \pm 2.08$ & 1.05 & $24.26 \pm 0.77$ & $10.72 \pm 0.35$ & $8.82 \pm 1.29$ & $20 \pm 4$ & $0.57 \pm 0.09$ & $0.7 \pm 0.14$ & $1.83 \pm 0.12$ \\
\hline$X$. spinosum & $\begin{array}{l}\text { Prolate- } \\
\text { spheroilda }\end{array}$ & $25.25 \pm 0.24$ & 1.05 & $24.03 \pm 1.14$ & $12.28 \pm 1.17$ & $1.18 \pm 0.18$ & $9 \pm 2$ & $1.39 \pm 0.31$ & $1.18 \pm 0.18$ & $2.18 \pm 0.17$ \\
\hline
\end{tabular}

Table 5. Details of examined characters of Xanthium sp. pollen specimens in this study (continued)

\begin{tabular}{|c|c|c|c|c|c|c|c|c|c|c|}
\hline Specimen & $\mathbf{L L}(\boldsymbol{\mu})$ & I $\mathbf{P}$ l) & $\operatorname{WET}(\mu)$ & $d(\mu)$ & $\mathbf{D}(\mu)$ & AI & $\mathbf{P S}(\mu)$ & $\mathbf{E T}(\mu)$ & $\mathrm{CT}(\mu)$ & TE \\
\hline$X$. brasilicum & $0.61 \pm 0.08$ & $\overline{0.18 \pm \overline{0.04}}$ & $0.15 \pm 0.03$ & $17.17 \pm 0.43$ & $25.85 \pm 0.78$ & 0.66 & $29.42 \pm 1.26$ & $3.44 \pm 0.58$ & $1.83 \pm 0.71$ & acute \\
\hline$X$. strumarium & $0.55 \pm 0.13$ & $0.18 \pm 0.04$ & $0.14 \pm 0.04$ & $16.99 \pm 0.62$ & $26.28 \pm 0.47$ & 0.65 & $30.75 \pm 1.29$ & $4.01 \pm 0.79$ & $2.19 \pm 0.41$ & acute \\
\hline X. sibiricum & $0.51 \pm 0.12$ & $0.12 \pm 0.04$ & $0.09 \pm 0.04$ & $17.8 \pm 0.96$ & $88.48 \pm 0.79$ & 0.63 & $29.81 \pm 3.36$ & $4.42 \pm 0.44$ & $2.14 \pm 0.23$ & acute \\
\hline x. spinosum & $0.39 \pm 0.1$ & 0 & 0 & $18.1 \pm 0.93$ & $28.14 \pm 0.93$ & 0.64 & $24.66 \pm 2.11$ & $2.61 \pm 0.33$ & $1.28 \pm 0.47$ & obtuse \\
\hline
\end{tabular}

Note: SP, shape of pollen shape; P, polar axis; E, equatorial diameter; P/E ratio, IC, interval between colpi; CL, colpi length; NE, number of echinae in $20 * 20 \mu \mathrm{m}^{2}$ area; IE, interval between two echinae; EL, echinae length; EW, echinae width in base; LL, length of lines on the surface of echinae; LET, length of echinae top; WET, width of echinae top; d, distance between the apices of two ectocolpi; D, equatorial diameter; AI, apocolpium index; PS, pollen size; ET, exine thickness; CT, cavea thickness; TE, type of echinae. 

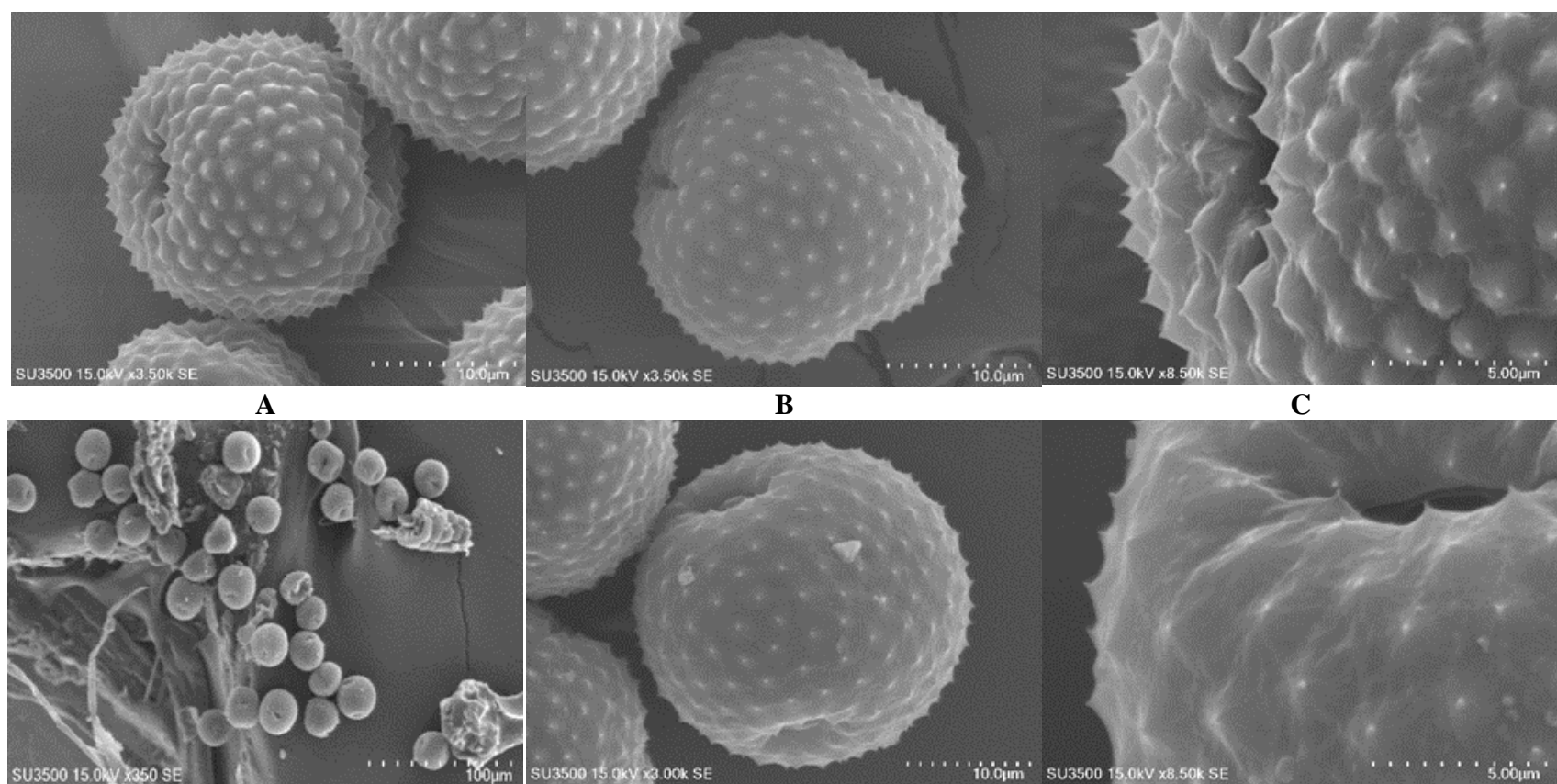

B

C
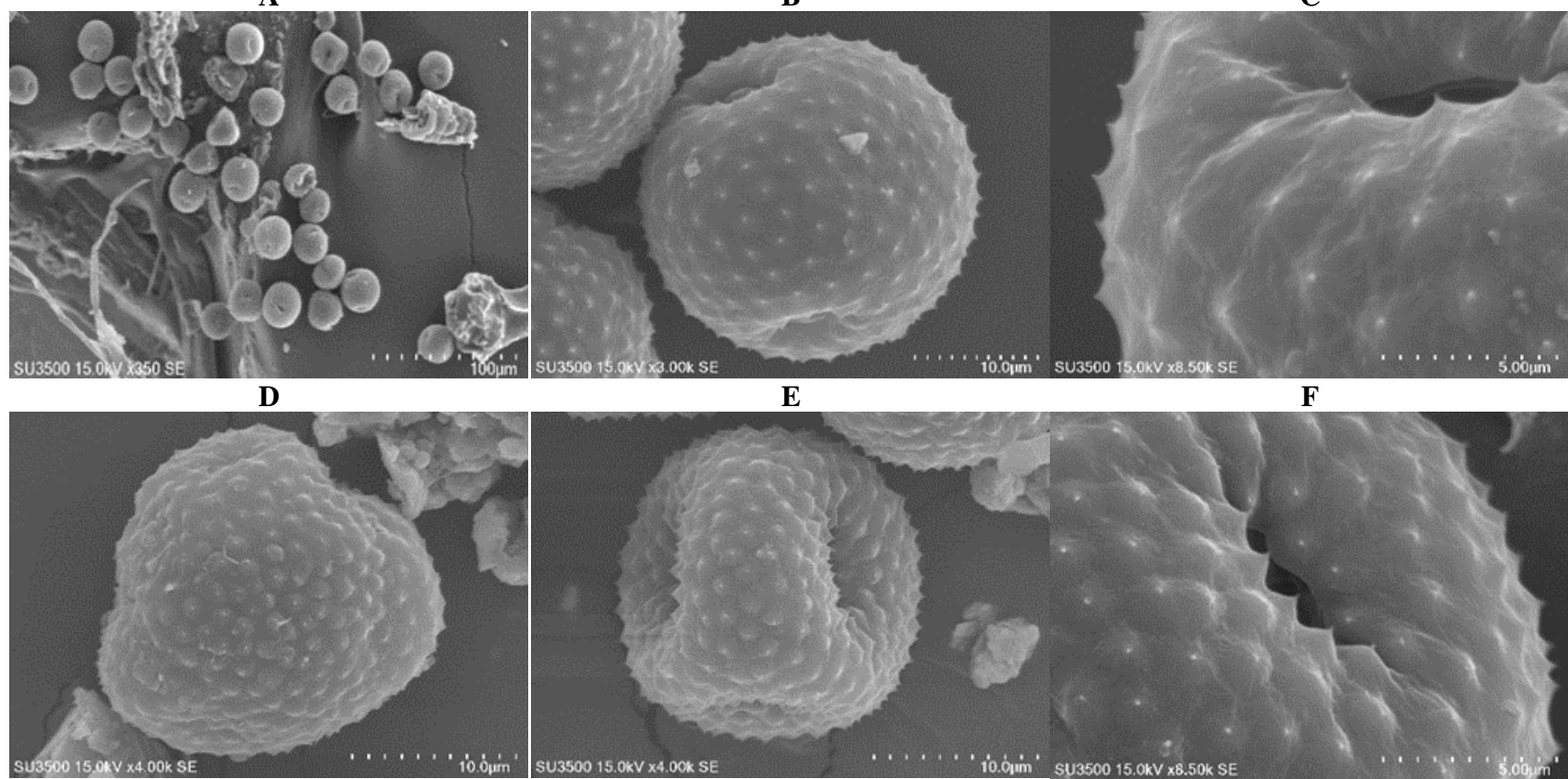

$\mathbf{E}$

F
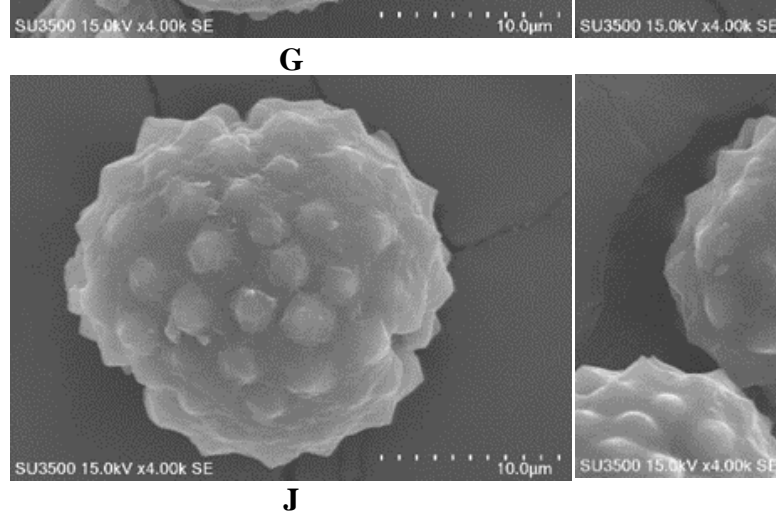

I

Figure 5. SEM micrograph of pollen grain in Xanthium L. A, B, C: X. brasilicum; D, E, F. X. strumarium; G, H, I. X. sibiricum; J, K, L. X. spinosum

Density and situation of spines ( \pm hook) and situation of beaks (parallel, divergent) determine their taxonomic boundaries. Furthermore, this taxonomic treatment is proposed in Flora of North America and Flora of Bolivia with only two species including $X$. spinosum and $X$. strumarium (Strother 2006; Hind 1993, 2011). On contrary, $X$. spinosum can be distinguished simply with obvious and characteristic characters in morphology and palynology, such as spiny stem, whitish at the beneath of leaves, leaf base and length, petiole length, ratio of leaf length to width, fruit shape, colpi length, number of echinae in $20 * 20 \mu \mathrm{m}^{2}$ area of pollen, echinae length, echinae width in base, length of echinae top, width of echinae top and type of echinae.

The multivariate analysis of morphological variation in the $X$. strumarium complex did not support separation of the complex into the three distinct species as described in Flora Iranica (Rechinger 1989). Results obtained from the PCoA analysis of morphological characters (Figure 1) showed that the three species, $X$. strumarium, $X$. brasilicum and $X$. sibiricum were placed nearly together specially $X$. strumarium and $X$. brasilicum are obviously overlapped in PCoA graph. 


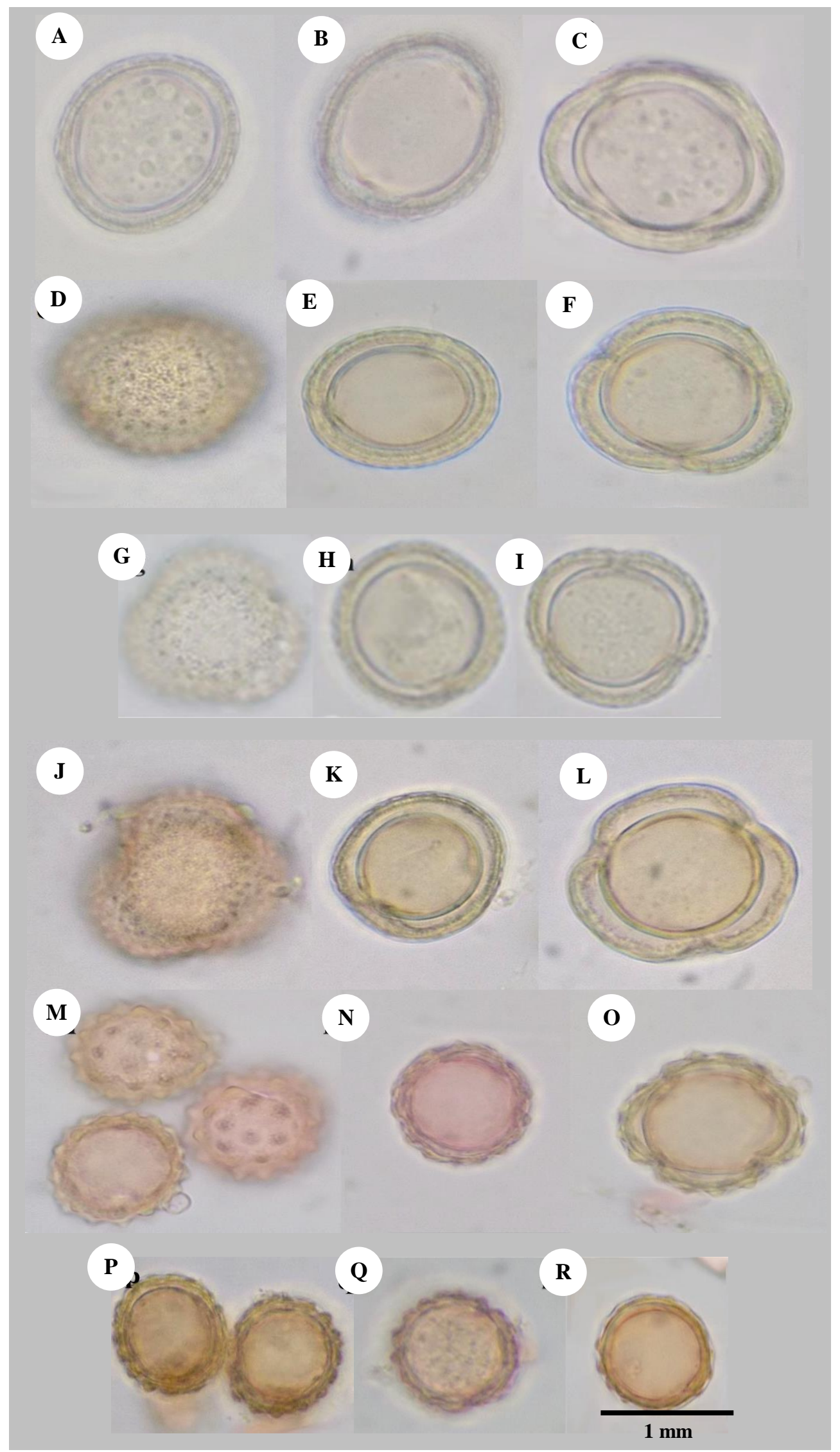

Figure 6. LM micrograph of pollen grain in Xanthium L.: A-C. X. brasilicum (Babol), D-F. X. brasilicum (Kiasar), G-I. X. strumarium, J-L. X. sibiricum, M-O. X.spinosum (Ghaemshahr), P-R. X.spinosum (Kiasar) 


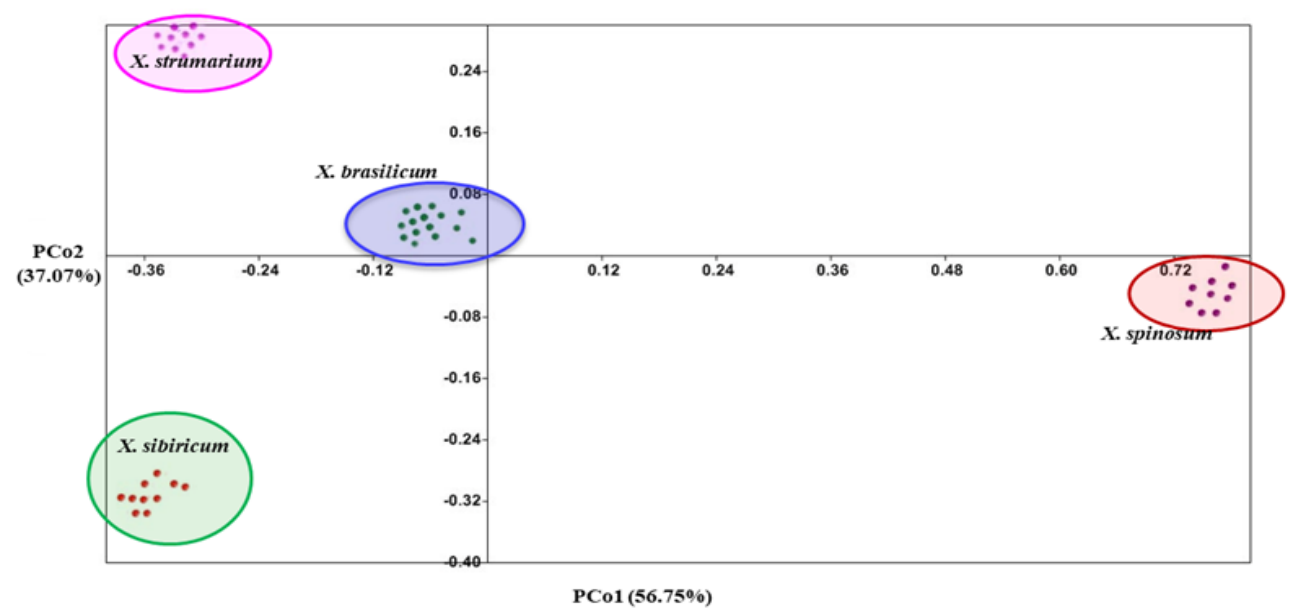

Figure 7. PCoA plot of pollen features of Xanthium sp.

Hindi (2011)

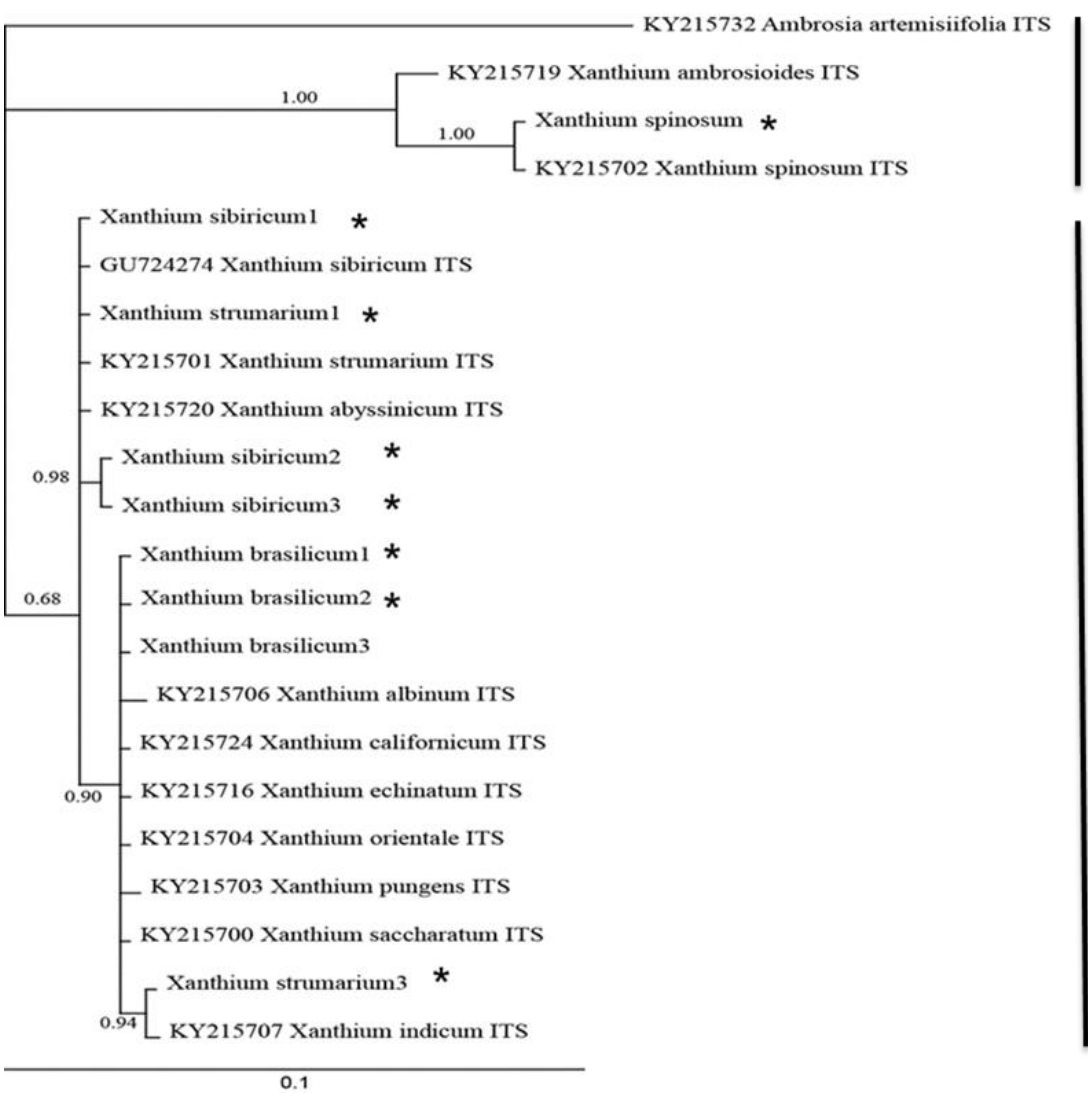

X. spinosum

X. Strumarium complex

Figure 8. ITS phylogenetic tree resulting from Bayesian analysis of the taxa understudy, 12 Xanthium species and one outgroup. Numbers above or below branches are posterior probability supports

Based on the first and second axis (principal coordinates) where the greatest amount of variance (totally $50.69 \%$ ) exists, there are no obvious boundaries separating $X$. strumarium, $X$. brasilicum and $X$. sibiricum. The three species can be separated only by a few vegetative characters such as the width of corolla and the ratio of corolla length to width. Likewise, this close relationship is also visible in the results of the PCoA of palynological characters (Figure 7) in which no differentiating traits could be identified to distinguish distinct species. Based on the first axis with the greatest amount of variance $(56.75 \%), X$. spinosum was isolated from the members of the complex. Moreover, the second axis of the multivariate analysis of the pollen features with the $37.07 \%$ variance 
could not also separate the Xanthium species complex. The results of palynological analysis of this study are inconsistent with the results of Pereira Coutinho et al. (2021) that showed the pollen grains of section Acanthoxanthium and Xanthium are clearly differed by their LM, SEM and TEM characters. However, no significant difference found between the pollen of $X$. strumarium subsp. strumarium and of $X$. strumarium subsp. brasilicum.

Therefore, our results showed abundant phenotypic plasticity in the $X$. strumarium complex species including extensive variation in shape, size and margins of leaves, fruit size, number and length of spines on the burs even within an individual. This is in accordance with the results of Moran and Marshall (1978) that showed Xanthium species in Australia had sufficient phenotypic plasticity to cope successfully with fluctuating environments without being dependent on broad genetic variation. Dinelli et al. (2003) indicated the same relevant phenotypic plasticity in Italian Xanthium species. Because of these obstacles in the genus, taxonomic classification affronts various insights: classification in several species and condensation to few highly polymorphic species. Results of Tomasello and Heubl (2017) supported the latter opinion, in spite of sequencing of four marker regions. Nonetheless, the results improved the identification of $X$. sibiricum by preparing specific restriction pattern. Moreover, Wallace et al. (2012) implied ITS2 sequencing for seven Xanthium species and indicated low divergence among these species in terms of informative sequence.

Hind (2011) in Flora of Bolivia considered a set of species including $X$. brasilicum, $X$. sibiricum, $X$. abyssinicum Wallr., X. californicum Greene, $X$. albinum (Widder) Scholz \& Sukopp, X. orientale L., X. echinatum Murray, $X$. pungens Wallr., $X$. saccharatum Wallr. and $X$. indicum DC. to be synonymous with $X$. strumarium. Similarly, X. ambrosioides Hook. \& Arn. is synonymous with $X$. spinosum. In summary, according to this Flora, all species that were previously defined as Xanthium have been synonymous with two species: $X$. strumarium and $X$. spinosum. The species with petiole subtended by an axillary 3-fid spine, rhomboid leaves that are whitish at the beneath and bur without or with 1 beak are considered to be $X$. spinosum and spineless plants with triangular concolorous leaves, cordate at base and bur with 2 beaks are defined as X. strumarium. Tomasello (2018) evaluated 34 Xanthium individuals from 12 species with molecular markers and coalescent-based species delimitation methods (BP \& P and STACEY) to determine species boundaries in Xanthium. He recognized five species in the genus Xanthium worldwide: $X$. spinosum L. And $X$. ambrosioides Hook \& Arn. on the one hand, and X. strumarium L., $X$. orientale L. and $X$. chinense Mill. (X. pungens) on the other, and provided an identification key.

However, our results obtained from the morphological, palynological and molecular study are in agreement with those proposed by Hind (2011) and Tomasello (2018) in which strongly supported scenarios with a reduced number of species. Our findings are inconsistent with Tomasello (2018) which revealed that in species tree reconstruction published by this author, the distance between the Acanthoxanthium and Xanthium section clades is always larger than the distances between the remaining clades (as shown in Fig1, 7 and 8), and Species in Xanthium section (Xanthium chinense, $X$. orientale, and X. strumarium) are traditionally characterized by their bur morphology but, as they frequently hybridize, an extensive number of transition morphotypes exist (Löve and Dansereau 1959; Pereira Coutinho and Paiva 2019). In summary, according to Tomasello (2018), two species of section Xanthium present in Iran $(X$. orientale and $X$. strumarium) that separate well by bur size and morphological features.

In conclusion, all species that were previously defined as Xanthium in Iran have been synonymous with three species: $X$. spinosum, $X$. strumarium and $X$. orientale $(X$. brasilicum and $X$. strumarium are considered to be synonymous with $X$. orientale and $X$. sibiricum are considered to be synonymous with $X$. strumarium). The species with petiole subtended by an axillary 3-fid spine, leaf blade lanceolate to ovate and 3-4 times longer than broader, burrs only lightly hairy that bearing 0-1 apical beak (if 2, then unequal) and erect to decumbent annual reaching $50-100 \mathrm{~cm}$ in height are considered to be $X$. spinosum and spineless plants with cordate to orbicular leaf blade and burrs bearing 2 equal beaks are defined as $X$. strumarium or $X$. orientale (X. strumarium: burrs glabrous and small, rarely exceeding $1 \mathrm{~cm}$ in length, with few, thin prickles and strait beaks and leaves to a large extent cordate; X. orientale: burrs generally hirsute, up to $3 \mathrm{~cm}$ long (including beaks), prickles uncinated and beaks straight or curved).

\section{ACKNOWLEDGEMENTS}

We thank Saeed Javadi Anaghizi (Central Laboratory of the Shahid Beheshti University, Tehran, Iran) for providing SEM photos.

\section{REFERENCES}

Alam SS, Sukur MB, Zaman MY. 2011. Karyotype analysis in 2 morphological forms of Xanthium strumarium L. Cytologia 76 (4):483-488. DOI: $10.1508 /$ cytologia.76.483.

Alorfi HS, Alshehry AA, Ghandourah MA, Bawakid NO, Elfaky MA, Ali AM, Alarif WM. 2020. Cytotoxic isoprenoids from Xanthium strumarium Linn. Phcog Mag 16 (70): 391-395. DOI: 10.4103/pm.pm_585_19.

Baldoni G, Viggiani P, Bonetti A, Dinelli G, Catizone P. 2000. Classification of Italian Xanthium strumarium complex based on biological traits, electrophoretic analysis and response to maize interference. Weed Res 40: 191-204. DOI: 10.1046/j.13653180.2000.00181.x

Barth OM, Melhem TS. 1988. Glossárioilustrado de Palinologia. Editora Unicamp, Campinas.

Bentham G. 1873. Notes on the classification, history and geographical distribution of the Compositae. Bot J Linnean Soc 13: 335-557.

Bickford D, Lohman DJ, Sodhi NS, Ng PKL, Meier R, Winker K, Ingram KK, Das I. 2007. Cryptic species as a window on diversity and conservation. Trends Ecol Evol 22: 148-155. DOI: 10.1016/j.tree.2006.11.004.

Blackmore S, Wortley AH, Skvarla JJ, Gabarayeva NI, Rowley JJ. 2010. Developmental origins of structural diversity in pollen walls of 
Compositae. Plant Syst Evol 284 (1-2): 17-32. DOI: 10.1007/s00606009-0232-2.

Blais PA, Lechowicz MJ. 1989. Variation among populations of Xanthium strumarium (Compositae) from natural and ruderal habitats. Am J Bot 76: 901-908. DOI: 10.1002/j.1537-2197.1989.tb15068.x.

Bordbar F, Mirtadzadini M. 2015. Palynological study of Jurinea (Asteraceae) and related genera from flora of Iran. Plant Syst Evol 301 (1): 151-162. DOI: 10.1007/s00606-014-1061-5.

Caius JF. 1986. Medicinal and Poisonous Plants of India. Pbl Sci Publ Jodhpur India 1: 375-376.

Chandel S, Bagai U, Vashishat N. 2012. Antiplasmodial activity of Xanthium strumarium against Plasmodium berghei-infected BALB/c mice. Parasitol Res 110 (3):1179-1183. DOI: 10.1007/s00436-0112611-1.

Cole RJ, Stuart BP, Lansden JA, Cox Rh. 1980. Isolation and redefinition of the toxic agent from cocklebur (Xanthium strumarium). J Agric Food Chem 28 (6): 1330-1332. DOI: 10.1021/jf60232a043.

Davis PH. 1975. Flora of Turkey and the East Aegean Island, Vol. 5. Edinburgh University Press, Edinburgh, UK.

Dinelli G, Bonetti A, Viggiani P. 2003. Genetic Structure and Mating System of Italian Xanthium strumarium Complex. Weed Sci 51 (1) 69-77. DOI: $10.1614 / 0043-1745$.

Dittrich M. 1989. Compositae VII. In: Rechinger KH (eds.) Flora Iranica, no. 164, pp 125, 83tab, Graz-Austria.

Doyle JJ, Doyle JL. 1987. A rapid DNA isolation procedure for small quantities of fresh leaf tissue. Phytochem Bull 19: 11-15.

Erdtman G. 1963. Palynology. In Advances in botanical research (Vol. 1) Academic Press.

Franco JA. 1984. Nova Flora de Portugal, vol. II, ClethraceaeCompositae. Lisboa: Escolar Editora.

Gautam R, Saklani A, Jachak SM. 2007. Indian medicinal plants as a source of antimycobacterial agents. J Ethnopharmacol 110 (2): 20034. DOI: $10.1016 /$ j.jep.2006.12.031.

Hall TA. 1999. BioEdit: a user-friendly biological sequence alignment editor and analysis program for Windows 95/98/NT. Nucleic Acids SympSer 41: 95-98.

Hammer O, Harper DAT, Ryan PD. 2009. Past version 1.91: Paleontological Statical Software package for education and data analysis. Palaeontol Electron 4: 4. https://palaeoelectronica.org/2001_1/past/issue1_01.htm

Hare JD. 1980. Variation in fruit size and susceptibility to seed predation among and within populations of the cocklebur, Xanthium strumarium L. Oecol 46: 217-222. DOI: 10.1007/BF00540129.

Hicks JA. 1971. Systematic studies of Xanthium (Compositae: Ambrosieae): The cockleburs of Tazewell country, Illinois [Dissertation]. University of Illinois, Urbana-champaign, IL

Hind DJN. 1993. Heliantheae. In: Hind DJN, Jeffrey C, Scott AJ (eds.) Flore des Mascareignes: La Rénion, Maurice, Rodrigues. 109. Composées. The Sugar Industry Research Institute, Mauritius; L'Institut Français de Recherche Scientifique pour le Développementen Coopération (ORSTOM), Paris \& The Royal Botanic Gardens, Kew.

Hind DJN. 2011. Annotated systematic checklist of the Compositae of Bolivia, version 2, Kew Gardens, UK.

Hocking PJ, Liddle MJ. 1986. The biology of Australian weeds: 15 . Xanthium occidentaleBertol. complex and Xanthium spinosum L. Aust J Agric Res 50: 191-221.

Hoffmann O. 1890. Compositae. In: Engler A, Prantl K, eds. Die Natürlichen Pflanzenfamilien, Vol. 4, 87-391. Leipzig: Verlag von Wilhelm Engelmann.

Isaac NJ, Mallet J, Mace GM. 2004. Taxonomic inflation: its influence on macroecology and conservation. Trends Ecol Evol 19: 464-469. DOI: 10.1016/j.tree.2004.06.004

Löve D, Dansureau P. 1959. Biosystematic studies on Xanthium: taxonomic appraisal and ecological status. Can J Bot 37: 173-208 DOI: $10.1139 / \mathrm{b} 59-016$

Löve D. 1976. Xanthium L. In: Tutin TG, Heywood VH, Burges NA Moore DM, Valentine DM, Walters SM, Webb DA, eds. Flora Europaea, vol. 4, Plantaginaceae to Compositae (and Rubiaceae), 143. Cambridge University Press, Cambridge.

Ma YT, Huang MC, Hsu FL, Chang HF. 1998. Thiazinedione from Xanthium strumarium. Phytochemistry. 48 (6): 1083-1085. DOI: 10.1016/S0031-9422(98)00084-3

Mace GM. 2004. The role of taxonomy in species conservation. Philos Trans R SocLond B 359: 711-719. DOI: 10.1098/rstb.2003.1454.
McMillan C. 1974. Experimental hybridization in Xanthium strumarium of American complexes with diverse photoperiodic adaptations. Can J Bot 52: 849-859. DOI: 10.1139/b74-107.

Moore AJ, Moore WL, Baldwin BG. 2014. Genetic and ecotypic differentiation in a Californian plant polyploid complex (Grindelia, Asteraceae). PLoS ONE 9 (4): e95656. DOI: 10.1371/journal.pone.0095656.

Moran GF, Marshall DR, Muller WJ. 1981. Phenotypic variation and plasticity in the colonizing species Xanthium strumarium (Noogoora Burr). Aust J Biol Sci 3634, 9-648. DOI: 10.1071/BI9810639.

Moran GF, Marshall DR. 1978. AlIozyme uniformity within and variation between races of the colonizing species Xanthium strumarium L. (Noogoora Burr). Aust J Biol Sci 31 (3) 283-292. DOI: 10.1071/BI9780283.

Nadeau LH. 1961. Etude biosystematique sur le gene Xanthium [Dissertation]. University of Montreal, Montreal, Canada.

Nlander JAA. 2004. MrModeltest v2. Program distributed by the author, Evolutionary Biology Centre, Uppsala University, Sweden. http://www.abc.se/*nylander/

Page DM. 2001. TreeView (Win32) Version 1.6.6. http://taxonomy.zoology.gla.ac.uk/rod/rod.html

Pereira Coutinho A, Almeida R, Sá da Bandeira D, Ortiz S. 2012. Pollen morphology in tribe Dicomeae Panero \& Funk (Asteraceae). Plant Syst Evol 298 (10): 1851-1865. DOI: 10.1007/s00606-012-0686-5.

Pereira Coutinho A, Dinis A. 2009. A light, scanning electron, and transmission electron microscopic study of pollen wall architecture in the subtribe Gnaphaliinae (Gnaphalieae, Asteraceae). Plant Syst Evol 283 (1-2): 79-92. DOI: doi.org/10.1007/s00606-009-0216-2.

Pereira Coutinho A, Paiva J. 2019. Xanthium L. In: Aedo C, Herrero A, eds. Flora Iberica - Plantas Vasculares de la Península Ibérica y Islas Baleares, Vol. 16, 2159-2165. Editorial CSIC, Madrid.

Pereira Coutinho A, Silveira P, Pita C, Santos MJ, Saraiva C, Perpétuo NC. 2021. Pollen morphology of Xanthium L. (sl) (Asteraceae, Asteroideae, Heliantheae, Ambrosiinae) in the Iberian Peninsula-a palynotaxonomic approach to a poisonous, allergenic and invasive genus. Grana 1760 (1): 35-56. DOI: 10.1080/00173134.2020.1737729.

Podani J. 2000. Introduction to the Exploration of Multivariate Data. Backhuyes, Leiden.

Punt W, Hoen PP, Blackmore S, Nilsson S, Le Thomas A. 2007. Glossary of pollen and spore terminology. Rev Palaeobot Palynol 143: 1-81. DOI: 10.1016/j.revpalbo.2006.06.008

Punt W, Hoen PP. 2009. The Northwest European Pollen Flora, vol. 70: Asteraceae-Asteroidea. Rev Palaeobot Palynol 157 (1-2): 22-183. DOI: 10.1016/j.revpalbo.2008.12.003.

Rambaut A, Drummond AJ. 2007. Tracer v 1.3. http://evolve.zoo.ox.ac.uk

Rechinger KH. 1989. Helianthae in K. H. Rechinger Flora Iranica, no 164: 33-40. Graz-Austria.

Sheidai M, Ziaee S, Farahani F, Talebi SY, Noormohammadi Z, Hasheminejad-Ahangarani-Farahani Y. 2014. Infra-specific genetic and morphological diversity in Linum album (Linaceae). Biologia 69 (1): 32-39. DOI: 10.2478/s11756-013-0281-4

Simmons MP, Ochoterena H. 2000. Gaps as characters in sequence-based phylogenetic analyses. Syst Biol 49: 369-381.

Skvarla JJ, Turner BL. 1966. Systematic implications from electron microscopic studies of Compositae pollen - A review. Ann Mo Bot Gard 53 (2): 109-164. DOI: 10.2307/2394944.

Skvarla, J.J., 1977. Pollen morphology in the Compositae and in morphologically related families. The biology and chemistry of the Compositae. Academic Press, New York.

Strother JL. 2006. Xanthium in: Flora of North America. Editorial Committee (eds.). Flora of North America, vol 21. Oxford University Press, New York.

Tellería MC, Sancho G, Funk VA, Ventosa I, Roque N. 2013. Pollen morphology and its taxonomic significance in the tribe Gochnatieae (Compositae, Gochnatioideae). Plant Syst Evol 299 (5): 935-948. DOI: 10.1007/s00606-013-0774-1

Thompson JD, Higgins DG, Gibson TJ. 1994. Clustal W: improving the sensitivity of progressive multiple sequence alignment through sequence weighting, position-specific gap penalties and weight matrix choice. Nucleic Acids Res 22: 4673-4680. DOI: 10.1093/nar/22.22.4673.

Tomasello S, Heubl G. 2017. Phylogenetic analysis and molecular characterization of Xanthium sibiricum using DNA barcoding, PCRRFLP and specific primers. Planta Med 83: 946-953. DOI: 10.1016/j.ympev.2018.05.024 
Tomasello S. 2018. How many names for a beloved genus? -Coalescentbased species delimitation in Xanthium L. (Ambrosiinae, Asteraceae). Mol Phyl and evol 127, 135-145. DOI: 10.1016/j.ympev.2018.05.024.

Tong C, Chen RH, Liu DC, Zeng DS, Liu H. 2020. Chemical constituents from the fruits of Xanthium strumarium and their antitumor effects. Nat Prod Commun 15 (8) 1-5. DOI: 10.1177/1934578X20945541.

Wagenitz G. 1976. Systematics and phylogeny of the Compositae (Asteraceae). Plant Syst Evol 125 (1) 29-46. DOI: 10.1007/BF00986129.

Wallace LJ, Boilard SM, Eagle SH, Spall JL, Shokralla S, Hajibabaei M. 2012. DNA barcodes for everyday life: routine authentication of natural health products. Food Res Intl 49 (1): 446-452. DOI: 10.1016/j.foodres.2012.07.048.

Weaver SE, Lechowich MJ. 1982. The biology of Canadian weeds. 56. Xanthium strumarium L. J Plant Sci 63: 211-225. DOI 10.4141/cjps83-021.
White TJ, Bruns T, Lee S, Taylor JW. 1990. Amplification and direct sequencing of fungal ribosomal RNA genes for phylogenetics. In: PCR protocols: a guide to methods and applications. Academic Press. New York.

Widder FJ. 1923. Die arten der Gattung Xanthium. Beitrage Zu einer monographie. Rep Spec Nov Regni Veg 20: 1-222.

Wortley AH, Blackmore S, Chissoe WF, Skvarla JJ. 2012. Recent advances in Compositae (Asteraceae) palynology, with emphasis on previously unstudied and unplaced taxa. Grana 51 (2): 158-179. DOI: 10.1080/00173134.2012.668219.

Wortley AH, Funk VA, Skvarla JJ. 2008. Pollen and the evolution of Arctotideae (Compositae). Bot Rev 74 (3): 438-466. DOI: 10.1007/s12229-008-9014-8.

Zhao X, Hu W. 2014. Application of ITS2 sequence as DNA barcode in Xanthium. Agric Biotechnol 3 (1): 19-21. 